UDK 531.

DOI 10.36910/6775-2313-5352-2021-18-16

A. Perederko, PhD

State University of Intelligent Technologies and Communications, Odessa, Ukraine.

\title{
THE USE OF A WAVELET TRANSFORMATION FOR REMOVAL OF THE NOISE COMPONENT FROM THE VIBRO SIGNAL
}

The article investigates the use of wavelets to remove noise from the measuring vibration signal. It is determined that wavelets are well adapted for signal analysis, for which the principle of causality is important: wavelets preserve the direction of time and do not create parasitic interference between the past and the future. Criteria for selecting an analytical wavelet have been developed, depending on what information should be extracted from the signal and the need to more fully identify and emphasize certain properties of the analyzed signal. It is proposed to use Daubechies wavelets to process the vibration signal data. The simulation of vibration signal filtering from noise with the normal distribution law is performed in the MATCAD package. It is proved that the method of wavelet transform allows to solve the problem of filtering the vibration signal from noise when processing vibration signals obtained by autonomous recording devices in conditions of increased interference from the environment. The obtained results evidence to the prospects of the developed method and its advantages in comparison with the hardware solution of the filtering problem.

Keywords: vibration signals, noise component of a signal, wavelet transform, threshold methods of signal processing.

Introduction. Modern means of control and diagnostics of units of machines and equipment are mostly based on the principles of measurement and analysis of vibration signals. This is due to the fact that vibration control in mechanical systems gives the largest amount of diagnostic information compared to methods such as temperature control, lubricant analysis and others. It follows that the vibration signal can detect almost all types of defects in the components of machines and equipment without the involvement of other types of physical processes for diagnosis. It is known that measurements during vibration diagnostics of equipment are carried out at the place of its operation. This leads to the impact on the measured signal of various industrial disturbances, which create in the measurement channel noise of complex amplitude-time implementation in a wide range of frequencies. These noises distort the vibration signal information and cause significant measurement errors.

That is due to the accuracy and reliability of the signal. The signal is of great importance.

Main part. Recently, there has been interest in other integral transformations, in particular, the wavelet transform (or discrete wave transform). It is used mainly for the analysis of nonstationary signals and for many problems of this kind it is more effective than the Fourier transform. The main difference of the wavelet transform is the decomposition of data not by a sine wave (as for the Fourier transform), but by other functions, that are called wavelet generators. Wavelet-forming functions, in contrast to an infinitely oscillating sine wave, are localized in some limited region of their argument, and far from it are zero or negligible.

The computational technique of wavelet transform allows to solve the problem of filtering (noise reduction) in relation to the spatio-temporal data obtained during vibration monitoring (when using threshold functions of different shapes, the level of detailing coefficients is limited) [1]. By setting a certain threshold for their level and "cutting off" the coefficients below this threshold, you can get a significant reduction in noise. It is proposed to use Daubechies mother wavelets to process the vibration signal data.

Since the wavelet transform is a scalar multiplication of the analyzing wavelet at a given scale and the analyzed signal, the coefficients of the scale-time spectrum $W(a, b)$ contain combined information about the analyzing wavelet and the analyzed signal (as well as Fourier transform coefficients containing information about the signal and about a sinusoidal wave). The choice of analyzing wavelet is usually determined by what information needs to be extracted from the signal. Each wavelet has characteristic features in time and frequency space, so sometimes with the help of different wavelets you can more fully identify and emphasize certain properties of the analyzed signal. 
Wavelets are well adapted for signal analysis, for which the principle of causality is important: wavelets preserve the direction of time and do not create parasitic interference between the past and the future.

It should be noted that when analyzing a complex one-dimensional signal or when using a complex analyzing wavelet as a result of wavelet transform, two-dimensional arrays of values of the modulus of coefficients and phase are obtained.

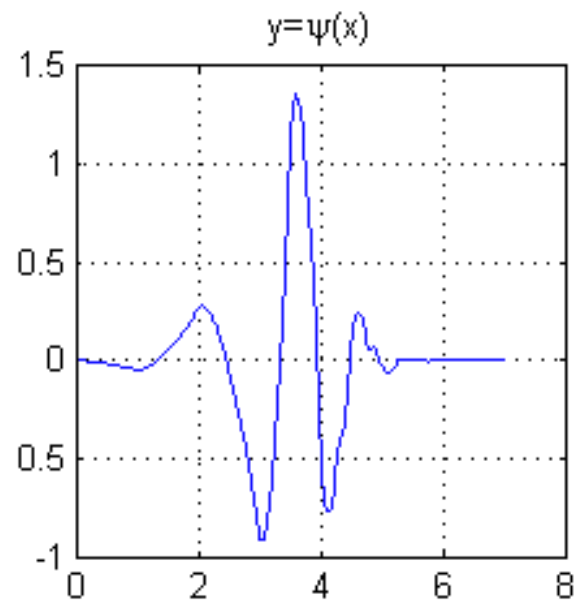

Fig.1. Mother Daubechies wavelet D4.

That is, the wavelet scale-time spectrum $W(a, b)$ in contrast to the Fourier spectrum is a function of two arguments: the time scale of the wavelet - $a$ (in units of inverse frequency), and the time offset of the wavelet on the signal- $b$ (in units of time), while the parameters $a$ and $b$ can take any value within the scope of their definition. The appearance of Daubechies orthogonal wavelet filters or so-called compact carrier filters has greatly increased interest in wavelet analysis, as new opportunities have opened up not only for the theoretical but also for the practical application of wavelet transforms.

It is important to note that Daubechies wavelet filters are built based on the criterion of filter length and, therefore, are filters with a finite number of coefficients [1]. It is customary to denote the wavelet functions $\psi(x)$ of Daubechies filters by the letter $\mathrm{D}$ with the addition of a number corresponding to the length of the Daubechies wavelet filter, ie D2, D4, D6, etc.

The theoretical basis of the computational technique for purification of the vibration signal from noise is the use of threshold functions of different shapes, based on which the level of detailing coefficients is limited $[2,8,9]$.

For the first time the idea of eliminating electrical noise from signals using wavelet transform originates in the work of Donohue and Johnstone [3,4], which proposes the use of a certain threshold to eliminate Gaussian white noise in electrical signals.

Thus, by setting a threshold of a certain level and "cutting off" the coefficients below this threshold, you can significantly reduce the noise level and compress the signal. A known example of threshold functions is presented in Fig.1. Figure 1 (a) shows a hard threshold function - hard (hard threshold evaluation), which is described by the following expression:

$$
y(x)= \begin{cases}x, & \text { if }|x| \geq T \\ 0, & \text { if }|x|<T\end{cases}
$$

Here, the value of $T$ is a certain threshold value, the possibility of determining which will be discussed below, as $x$ and $y$ are the input and output values of the conversion coefficients. Figure 2 (b) presents a soft threshold function (soft threshold evaluation), which is described by the following expression:

$$
y(x)= \begin{cases}\operatorname{sign}(x) \cdot(|x|-T) & \text { if } \quad|x| \geq T \\ 0, & \text { if } \quad|x|<T .\end{cases}
$$


The notation given in expression (2) is the same as described above in (1). The option sign ( $x$ ), that determines the sign of the coefficient $x$, is a function of the form:

$$
\operatorname{ign}(x)= \begin{cases}1, & \text { if } \quad x>0 \\ 0, & \text { if } \quad x=0 \\ -1, & \text { if } \quad x<0\end{cases}
$$

It is known that the main difference between the soft threshold function and the hard one is that the first of them does not contain a gap at a point determined by the limit value $T[1,5]$. In other words, the soft threshold function, unlike the hard one, is continuous. The latter circumstance, in the case of soft threshold processing, allows the best way to process a noisy vibration signal in the vicinity of the point of its rupture.

The question arises: which threshold function is better for noise filtering. Additionally, a computational experiment allows us to note the following features of the threshold functions hard and soft:

- the hard function acceptably works at a low noise level, when all the noise coefficients of decomposition by modulo less than the threshold $T$ and they are respectively zeroed, and all informative coefficients exceed the modulus threshold $T$ and therefore they are stored;

- the absence of a soft gap in the vicinity of point $a$ (see Fig. 2) to some extent prevents the appearance of oscillations (Gibbs effect) at special points of the signal. This effect can occur when using the hard threshold function.

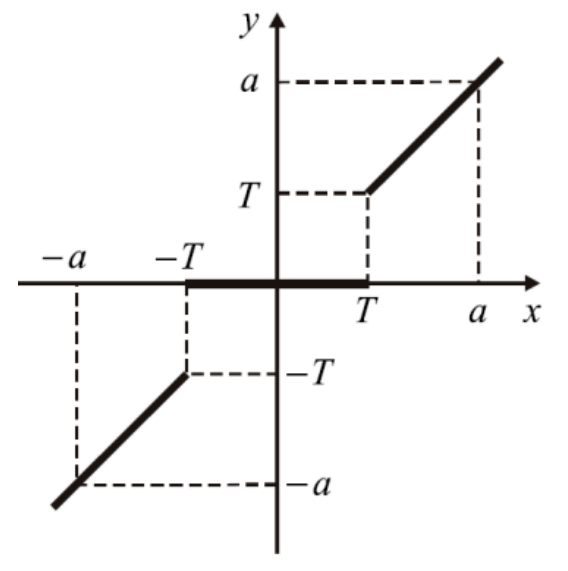

a)

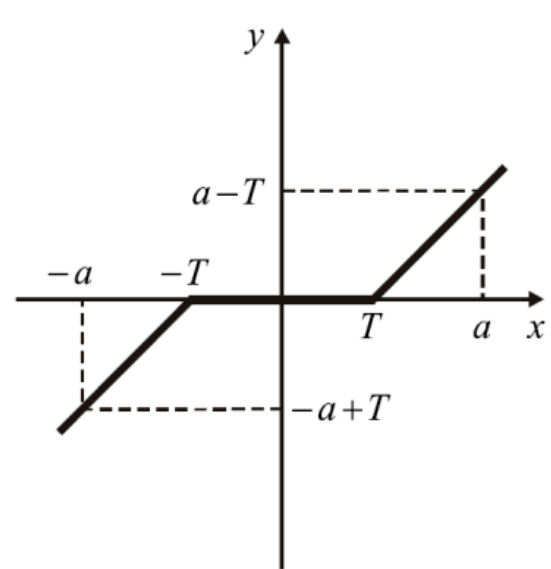

б)

Fig.2. Marginal processing functions of transformation coefficients:

a) hard - hard threshold function; б) soft - soft threshold function.

Reducing the value of the decomposition coefficients by the threshold value, in the case of soft threshold processing, in General for a large number of signals has a negative impact on the final assessment of the quality of the recovered signal. Experiments show that a rigid threshold estimate is more preferable in terms of numerical evaluation of the quality of the recovered signal. According to research in $[4,6,7]$, in order for the numerical evaluation of the recovered signal to approach the latter in the case of hard threshold processing in the case of soft threshold processing, it is necessary to choose a threshold value $T$ equal to half the value of the hard signal processing threshold. It is known that the main problem of using threshold processing methods is the choice of threshold value. Typically, the choice of threshold was made using the following expression:

$$
T=\sigma \sqrt{2 \ln (N)}
$$

Formula (4) is written for the case of a one-dimensional signal (in our case, a vibration signal from a uniaxial accelerometer). The formula uses the following notation: $N$ is the total number of samples of the processed signal, $\sigma$ is the standard deviation of the noise: 


$$
\sigma=\frac{M_{x}}{0,6745},
$$

where $M_{x}$ is the median of the absolute value of the set of coefficients $\{X\}$. Since wavelets are widely used to solve the problem of noise reduction, it is advisable to use them to process the vibration signal when monitoring the technical condition of the equipment. The results of solving the problem of signal noise filtering when measuring vibration are shown in Fig.4 (based on Daubechies wavelets). The results were obtained by modeling the filtering of the vibration signal with a noise component (Gaussian noise) in the MATCAD package.

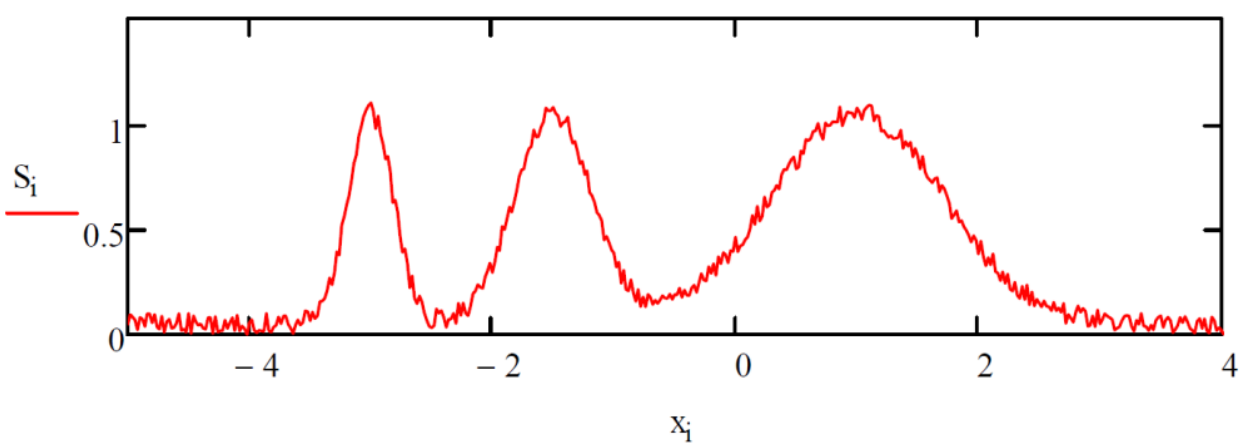

Fig.3. Image of the vibration signal model with noise.

Fig. 3 shows the vibration signal with a noise component. When performing in the MATCAD $[6,7,10]$ environment of the above simulation, to simulate the vibration signal, a signal of complex frequency implementation was used. To simulate the noise component, a pseudo-random signal with a normal distribution law is superimposed on the specified signal.

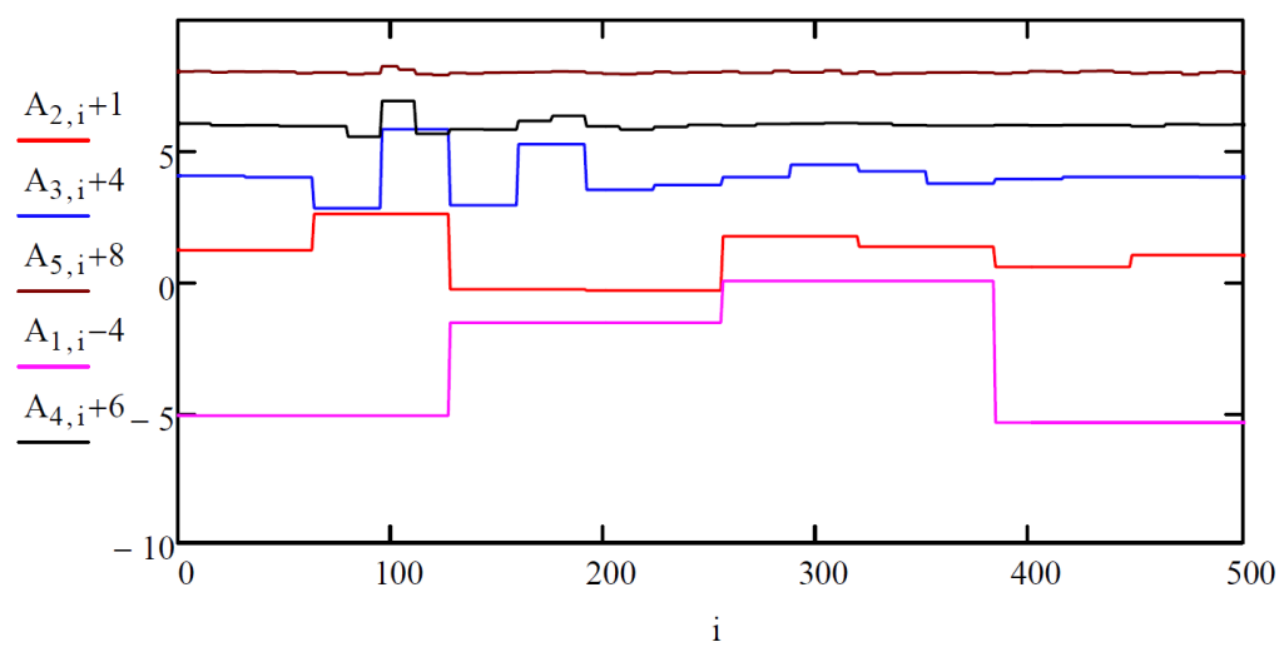

Fig.4. The wavelet spectrum of the Daubechies model signal. The results of calculations of the Daubechies wavelet spectrum are presented in the form of five families of its coefficients.

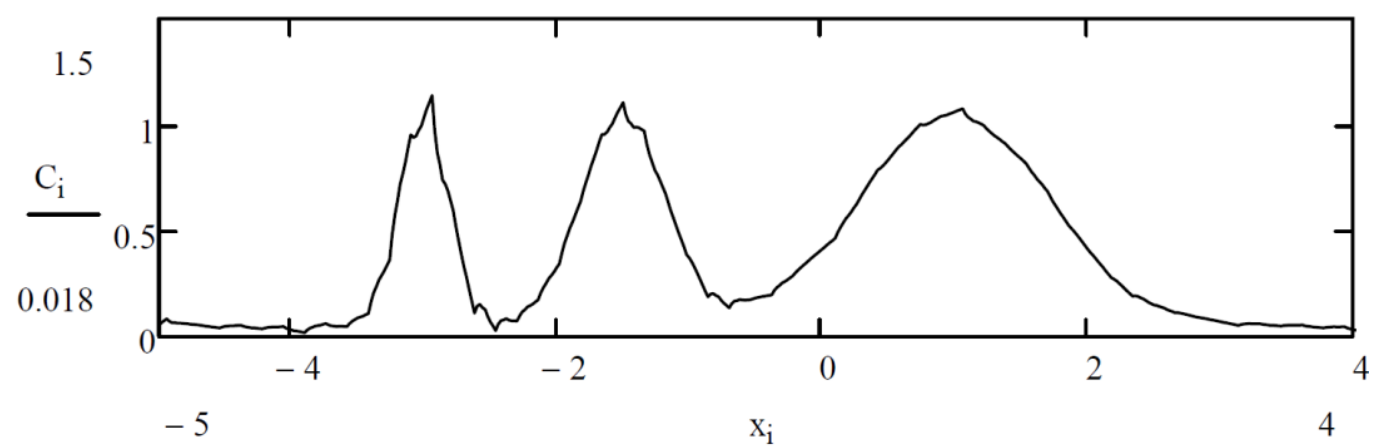

Fig.5. Image of the processed input signal without noise, that was eliminated as the result of the inverse wavelet transform. 


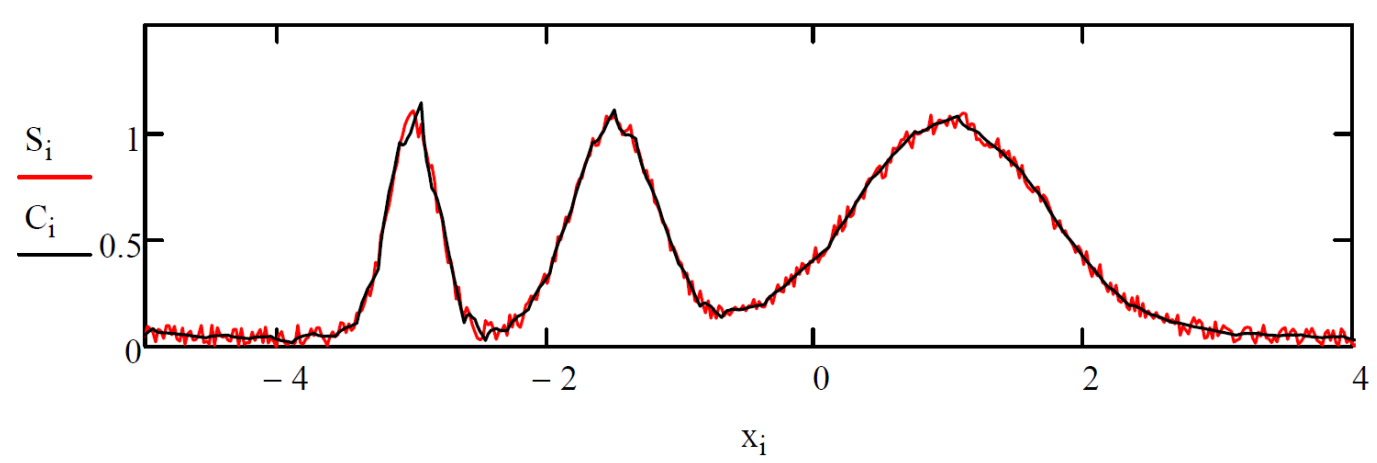

Fig.6. Image of the input signal with noise ( $\mathrm{Si}$ ) and the purified signal (Ci), without the noise, that was eliminated as the result of the inverse wavelet transform.

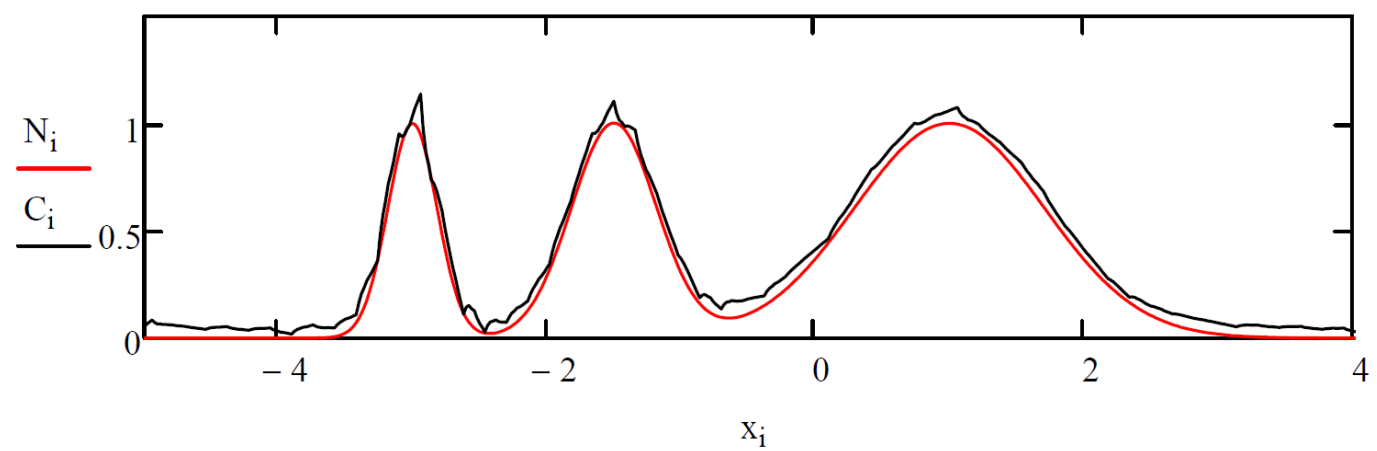

Fig.7. Image of the input signal without noise $(\mathrm{Ni})$ and the cleared signal $(\mathrm{Ci})$.

Fig. 7 shows a comparison of the playback accuracy relative to the initial signal of the simulation of the vibration signal $\mathrm{Ni}$ (signal $\mathrm{Si}$ without noise component) and the signal recovered after filtering from noise.

As can be seen from the figure, in general, the restored signal, with small differences, fully reproduces the useful signal in both amplitude and frequency implementations.

Conclusion. In this paper, the simulation of vibration signal filtering from noise with the normal distribution law in the MATCAD package is performed. The obtained results show that the wavelet transform method allows to solve the problem of filtering the vibration signal from noise. The obtained results evidence to the prospects of the developed method and its advantages in comparison with the hardware solution of the filtering problem. It can be concluded that in many cases this method can be used in the processing of vibration signals obtained by autonomous recording devices in conditions of increased interference from the environment.

1. Daubechi I. Desyat lekczij po vejvletam. - Izhevsk: NICz «Regulyarnaya i khaoticheskaya dinamika», 2001, - $464 \mathrm{~s}$.

2.Voskobojnikov Yu. E. Postroenie algoritmov vejvlet-fil traczii s dvukhparametricheskimi porogovy`mi funkcziyami / Yu. E. Voskobojnikov, A. V. Gochakov // Avtometriya. -2012. - T. 48, \# 1. - S. 17-29.

3. Ajficher E`. Czifrovaya obrabotka signalov: prakticheskij podkhod. 2-e izd. / E`.Ajficher, B. Dzhervis //M.: Vil yams, 2004.

4. Mitrakhovich M. M. Ispol'zovanie vejvlet-preobrazovaniya v zadachakh diagnostirovaniya tekhnicheskogo sostoyaniya gazoturbinny'kh dvigatelej / M. M. Mitrakhovich // Tekhnologicheskie sistemy`. - 2014. - \# 3 (68). - S. 22-26.

5. Kavchuk S.V. Sbornik primerov i zadach po teorii signalov: Rukovodstvo dlya prakticheskikh zanyatij na baze Mathcad 6.0 Plus/ S.V. Kavchuk// Taganrog,Izd-vo TRTU, 2001.

6. Makarov E. Inzhenerny`e raschety`v Mathcad-15/ E.Makarov // SPb.: Piter, 2011.

7. Daubechies I. The Wavelet Transform, Time-Frequency Localization and Signal Analysis // IEEE Trans. Inform. Theory, 1990, № 5. p. 961-1005.

8. Sergienko A.B. Czifrovaya obrabotka signalov. - SPb.: Piter, 2003. -604 s. 
9. Astafeva N.M. Vejvlet-analiz: osnovy` teorii i nekotory`e prilozheniya // Uspekhi fizicheskikh nauk, 1996, \# 11. S. 1145-1170.

10. Goswami J.C., Chan A.K. Fundamentals of Wavelets. Theory, Algorithms, and Applications. Wiley, 2000. - 306 p.

\section{А. Передерко \\ ВИКОРИСТАННЯ ВЕЙВЛЕТ ПЕРЕТВОРЕННЯ ДЛЯ ВИДАЛЕННЯ ШУМОВОЇ СКЛАДОВОЇ 3 ВІБРОСИГНАЛУ}

Стаття досліджує використання вейвлетів для усунення шуму від вимірювального вібрачійного сигналу. Визначено, що вейвлети добре пристосовані для аналізу сигналів, для чого важливий принции причинності: вейвлети зберігають напрямок часу і не створюють паразитарних втручань між минулим і майбутнім. Розроблено критерії вибору аналітичного вейвлету в залежності від того, яку інформацію слід витягнути із сигналу, та необхідності більш повно визначити та підкреслити певні властивості аналізованого сигналу. Для обробки даних сигналу вібрації пропонується використовувати вейвлети Daubechies. Iмітаиія фільтрації вібраційних сигналів від шуму за нормальним законом розподілу виконується 6 пакеті МАTCAD. Доведено, що метод вейвлет-перетворення дозволяє вирішити проблему фільтраиії вібраційного сигналу від шуму при обробиі вібрачійних сигналів, отриманих автономними реєструючими пристроями, в умовах підвищених перешкод від навколишнього середовища. Отримані результати свідчать про перспективи розробленого методу та його переваги в порівнянні з апаратним вирішенням проблеми фільтрачіï.

Ключові слова: вібрачійні сигнали, шумова складова сигналу, вейвлет-перетворення, порогові методи обробки сигналів.

\section{А. Передерко}

\section{ИСПОЛЬЗОВАНИЕ ВЕЙВЛЕТ ПРЕОБРАЗОВАНИЯ ДЛЯ УДАЛЕНИЯ ШУМОВОЙ СОСТАВЛЯЮЩЕЙ С ВИБРОСИГНАЛА}

В статье исследуется использование вейвлетов для удаления шума из измеряемого сигнала вибрачии. Определено, что вейвлеты хорошо адаптированы для анализа сигналов, для которого важен принщи причинности: вейвлеть сохраняют направление времени и не создают паразитных помех между прошлым и будущим. Критерии выбора аналитического вейвлета были разработаны в зависимости от того, какая информачия долюсна быть извлечена из сигнала, и от необходимости более полно идентифицировать и подчеркивать определенные свойства анализируемого сигнала. Предлагается использовать вейвлеты Добеши для обработки данных сигнала вибрачии. Моделирование фильтрации вибросигнала от шума с нормальным законом распределения выполняется в пакете МАTCAD. Доказано, что метод вейвлет-преобразования позволяет решить задачу фильтрации вибросигнала от шума при обработке вибросигналов, полученных автономными регистрирующими устройствами в условиях повыменных помех со стороны окружающей среды. Полученные результатьл свидетельствуют о перспективности разработанного метода и его преимуществах по сравнению с аппаратным решением задачи фильтрачии.

Ключевые слова: вибрачионные сигналы, шумовая составляющая сигнала, вейвлетпреобразования, пороговые методы обработки сигналов. 